thoroughly reliable make of engine, the saving on fuel alone over a period of five years was stated to be rather more than twice the initial cost of conversion.

\section{Suggested Museum for Croydon}

Croydon now has an excellent opportunity of building a museum worthy of the town. A large area of ground of several acres has lately been acquired from the Southern Railway Company, but at present the proposed lay-out of the area does not foreshadow a museum. There will be a technical college, art school, with other public buildings, and the Corporation could now very appropriately consider the establishment of a museum. The large bequest of Dr. Franklin Parsons of a good many years ago is still unexhibited, and the small museum at Grangewood Mansion has been from time to time curtailed, in order to provide schoolrooms. There is a wealth of material waiting to find a place in a public museum, and the educational facilities of the town are not complete until it possesses a wellstocked museum. The population of the borough approaches a total of a quarter of a million, and it must be difficult to find a borough of the same dimensions that has so far not seen fit to equip itself with a suitable museum. Now a site offers itself, and it is to be hoped that the Corporation will rise to the occasion.

\section{B.M.A. Fund for Research in Australia}

A CORRESPONDENT in Melbourne writes: "Readers of NATURE may be interested to know that the British Medical Association meeting in Melbourne in September last wound up with a surplus of about

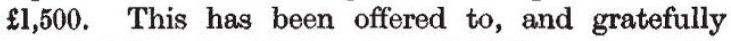
accepted by, the University of Melbourne as the nucleus of a special fund for medical research. We have in Melbourne two excellent medical research organisations, namely, the Walter and Eliza Hall Institute at the Royal Melbourne Hospital and the Baker Institute at the Alfred Hospital. But some of us feel that we want a fund which can be devoted to the aid of someone recommended for a particular piece of work terminable when the work is finished. The members of the permanent staff of these institutes have a good deal of routine work to do--essential and valuable--but here and there someone is found who wants to extend the boundaries of knowledge and wants help and guidance. Hence this fund, of which we are somewhat proud, as Congresses do not generally end with a credit balance. The senior medical men worked hard and organised excellently."

\section{Nationalism and Soil Erosion}

A STRIKING connexion between physical geography and economic policy is outlined by Prof. C. F. Shaw in the Geographical Review for January. He points out that the upland soils of much of Great Britain are shallow. In England and Wales they average twenty-five inches in depth and in Scotland, where glacial deposits are more general, forty inches. Chalk soils of southern England are the thinnest, averaging only ten inches. On all these upland soils erosion, though not conspicuous, is active. Evidence is obtainable from remains of Roman occupation and other sources as shown at the recent International Congress of Soil Science held at Oxford. Prof. Shaw's contention is that economic pressure, exerting itself in increased grain production in the home country, will entail the ploughing of sloping uplands, which will loosen the soil cover and so promote more active erosion. This will in turn impoverish the uplands and cause further deposition of soil on the lowlands. A sounder economic policy is in his opinion the preservation of the thin upland soils by maintaining them under grass, which would at least ensure their continued usefulness as grazing grounds for food animals.

\section{Insurance Against Price Fluctuations}

Discussing some statistical aspects of future trading on a community exchange, Mr. G. R. White, in a paper read recently before the Royal Statistical Society, remarked that, during the past ten years, 'future' trading has spread rapidly and now covers commodities such as coffee, cocoa, sugar, butter, eggs, pepper, vegetable oils, shellac, wool tops, hides, rubber, silk, jute, tin, copper and zinc, in addition to grain and cotton, in which future trading has been an established practice for upwards of seventy years. Supporters of the system claim that, among other things, future trading reduces major fluctuations in prices, and provides a method of price insurance through 'hedging'. Mr. White, selecting for the purpose of his investigation future trading in hides, controverted this assumption; he concludes that there is no evidence that fluctuations in the price of hides have been reduced since a future exchange was established for this commodity in New York in 1929. In fact, he says the evidence trends in the opposite direction. 'Hedging' on the Hide Exchange has only provided imperfect price insurance. He suggests that more attention should be paid to evolving a method of insurance more akin to that evolved for other insurable risks, and taking data of the past fourteen years, he calculates that the premiums necessary to insure over a period of twenty weeks against either a fall or rise in price would not be prohibitive.

\section{Malvern College Natural History Society}

THE twelfth report of this Society (1935) contains an article by J. W. B. Waring on minute pond organisms, well illustrated by original drawings from the living material, both plant and animal. The author has collected samples of ooze from a number of ponds including an artificial gold fish pond in his garden, and records his own observations on the life in these ponds. Such work is valuable, and should be encouraged in every way. An article on the history of the Malvern College Natural History Society shows that it dates from 1868, when the Malvern Naturalists' Field Club was transferred to the College. The present membership is thirty-six, and it is to be hoped that the number will increase considerably. 